\title{
Treatment of Fibropapillomatosis in a Green Sea Turtle (Chelonia mydas) Using Ultra-Diluted: Case Report
}

\author{
Franscinne Brait Narita ${ }^{1,2,3 *}$, Melina Castilho de Souza Balbueno ${ }^{1,2}$, Bruna Scardoeli ${ }^{2}$, Hugo Gallo Neto ${ }^{3,4}$ and Cidéli de Paula Coelho ${ }^{1,2}$ \\ ${ }^{1}$ Department of Veterinary Medicine and Animal Welfare, University of Santo Amaro, São Paulo, São Paulo, Brazil \\ ${ }^{2} \mathrm{HD}$ Science School, São Caetano do Sul, São Paulo, Brazil \\ ${ }^{3}$ Institute Argonauta para Conservação Costeira e Marinha, Ubatuba, São Paulo, Brazil \\ ${ }^{4}$ Aquário de Ubatuba, Ubatuba, São Paulo, Brazil
}

${ }^{\star}$ Corresponding author: Franscinne Brait Narita, Department of Veterinary Medicine and Animal Welfare, University of Santo Amaro; Address: Prof. Enéas de Siqueira Neto, 340, Jardim das Imbuias, São Paulo/Brazil; Tel: +55 11 98118-5234; E-mail: frannarita.homeopatia@gmail.com

Received: May 14, 2021; Accepted: May 28, 2021; Published: May 31, 2021

\begin{abstract}
Fibropapillomatosis (FP) is an infectious, neoplastic disease, frequently found in sea turtles, whose prevalence may be associated with environmental factors and predisposition, generally associated to herpesviruses presence, compromising, their locomotor, ocular and food apprehension performance. In the present report, the presentation of fibropapillomas occurred in the ocular region. The diagnosis is based on physical examination, histological and PCR, while conventional treatment involves surgical removal of tumors, cryosurgery and electrochemotherapy, accompanied by recurrences. However, at present, we chose homeopathic treatment with Thuya occidentalis $30 \mathrm{cH}$, in which it was effective and less harmful to the patient, since there were no recurrent conditions.
\end{abstract}

Keywords: Fibropapiloma, Homeopathy, HPV, Thuya

\section{Introduction}

Fibropapillomatosis (FP) is a neoplastic infectious debilitating disease, commonly found in sea turtles, presenting multiple, large and ulcerated skin masses, characterizing the presence of fibropapilloma and internal fibroma that compromise locomotion and food apprehension [1]. The origin can be developed as a result of environmental factors and genetic predisposition, usually caused by a herpesvirus [2,3] with latency capacity in the host organism [4]. Thus, being the prevalence of the disease associated with unfavorable environmental conditions, it is possible through it, monitor the state of ecosystems [5].

FP is also considered a panzootic and emerging disease, threatening the conservation of the species, in addition to causing serious locomotor damage, in vision, in the food apprehension and increasing the predisposition to secondary diseases [2,6,7]. Conventional treatment for FP involves surgical removal of tumors, cryosurgery and electrochemotherapy, subject to complications $[8,9]$, while the cure of homeopathic treatment promoted by the administration of Thuya occidentalis, is lasting effectiveness and also less harmful [10].

\section{Case Report}

One green turtle (Chelonia mydas), juvenile, female, with free life, found on the Itaipuaçú beach, in Maricá in Rio de Janeiro State

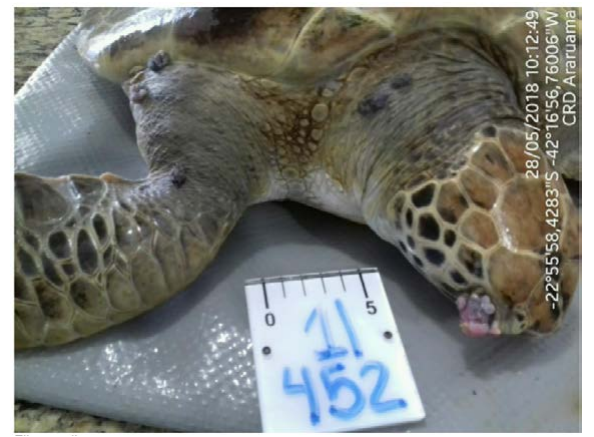

Figure 1A: 04/28/2018

(Figure 1A), presenting fibropapillomatosis in several areas of it body and in the right cornea, being submitted to 4 surgical procedures to remove the fibropapillomas, because its always presented recurrence and evolution in the size of the fibropapilloma of the right eye region.

Considering the enucleation of the left eye of the sea turtle and impaired vision of the right eye, it was not possible to reintroduce it into nature, being forwarded to Sabina - Escola Parque do Conhecimento, located in Santo André/SP (Figure 1B).

Given the above, we opted for homeopathic treatment with Thuya occidentalis $30 \mathrm{cH}$ on $01 / 23 / 2019$, whose treatment evolution was monitored weekly through biometrics and photographic record of fibropapilloma. 


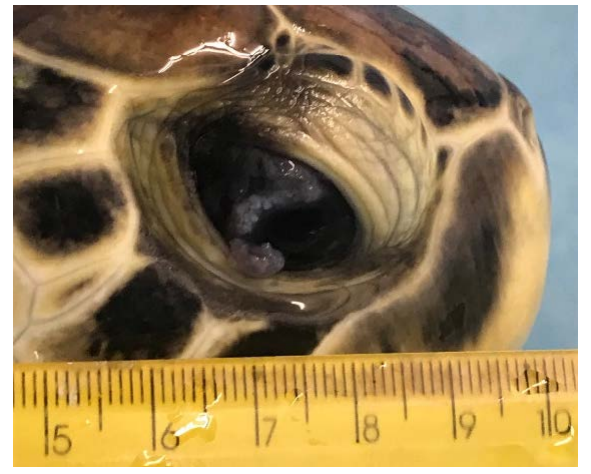

Figure 1B: 01/23/2019.

In March 2019, it was observed that fibropapilloma remained stable, but without size evolution, as observed in the previous conventional treatment. The administration of HPV Biotherapic $30 \mathrm{cH}$ was added to the protocol, which after 15 days, there was regression of the size of the fibropapilloma (Figure 2). In the month of July 2019 it was entitled to increase the potency of the HPV biotherapic to $200 \mathrm{cH}$ and decrease its frequency once a week until March 2020, attesting to complete regression without recurrence (Figure 3).

\section{Discussion}

The origin of fibropapillomatosis is infectious as a result of environmental factors, such as climate change, environmental degradation and especially the human disturbances in marine

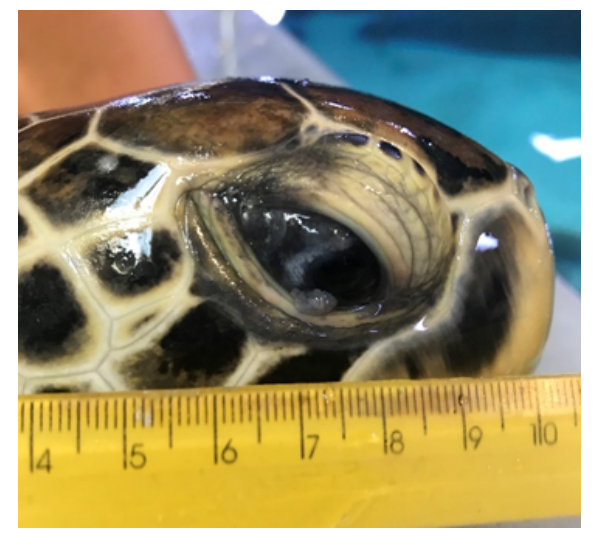

Figure 2: 03/27/2019

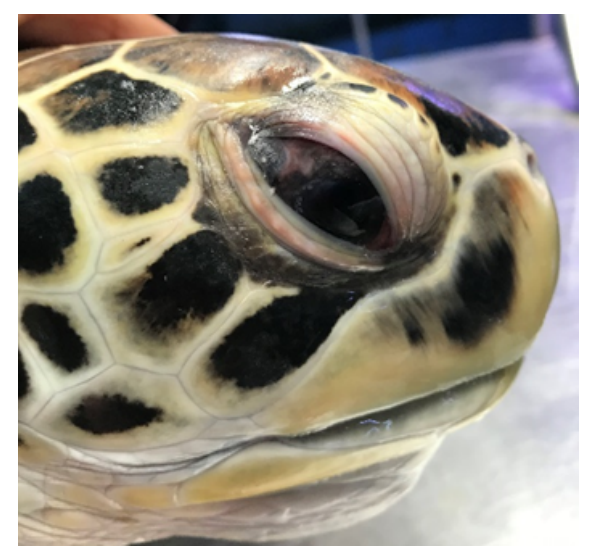

Figure 3: 04/17/2020. environments [11] and genetic predisposition, that the transmission is caused by a herpesvirus, as evidenced in research carried out by Tamar Project with FMVZ - USP [2]. The study confirmed the presence of Chelonid Alphaherpesvirus 5 (ChHV5) associated with fibropapillomatosis in three types of tissue: skin, tumor and blood sample [12]. Research shows that in Florida and Caribbean, this disease is expanding, but in the other hand, decreasing in Hawaii [13]. This fact can be associated with the divergence of nucleotides between populations [14]. The most memorable feature of the virus is it latency capacity in the host organism, remaining in the infected animal's organism for long periods, entering the active phase of the infection, in moments of homeostatic discontinuity $[4,15]$.

Tumors are more frequently located in the soft tissue of the turtles' skin, at the base of the tail, close to the eyes and in the oral, cervical, inguinal, axillary and hull regions, causing impairment in the functioning of the purposes, vision and increased susceptibility diseases of associated eye structures, food apprehension, breathing and efficiency in the escape of predators [2,6]. In the present report, the presentation of fibropapillomas occurred in several areas of the body, including the ocular region. The frequency in the cranial region, including the ocular region, was only $1.01 \%$ of the cases, while the most frequent area is the fins region (47.05\%) [7]. Corroborating, a study only 4 of the 787 animals $(0.5 \%)$ were found with corneal fibropapillomas with varieties sizes, similar thickness and microscopic characteristics, different as reported in others studies (United States and Hawaii) [6].

That it may have a relationship of environmental change, showing that the prevalence of the disease is associated with water quality, pollution of coastal areas, areas with high human density, large contribution of agricultural, domestic, industrial and marine biotoxins, in such a way that the etiology of fibropapillomatosis can also serve to monitor the health of ecosystems $[10,5,16]$. A study with organic pollutant, polycyclic aromatic hydrocarbons, showed that turtles with FP had higher concentrations of this pollutant in the liver, than those that did not have FP [16]. Affected animals may also present impaired status, fluctuation disorders, cachexia, hypoproteinemia, uremia and elevation of liver enzymes, while in hematological indices, non-regenerative anemia, progressive decrease in lymphocyte count, basophils and eosinophils and progressive increase in heterophiles and monocytes [2].

Comparatively, the patient presented anemia in the first exam, which it obtained normalization in the new exam after 1 year, as well as an improvement in leukopenia from 8 thousand $/ \mathrm{mm}^{3}$ to 11.6 thousand $/ \mathrm{mm}^{3}$; normalized lymphopenia from $9 \%$ to $20 \%$; and ALT that wes increased by $35 \mathrm{U} / \mathrm{L}$, decreasing to $25 \mathrm{U} / \mathrm{L}$. Macroscopically the tumor lesions varying from smooth to verruciform with small pointed projections, pigmented of white, pink, red, grayish, purple or black color, also varying in size and conditions of ulceration and necrosis $[1,2]$. In the case of the present report, the lesions were whitish with a rough appearance.

Conventional treatment recommends surgical removal of tumors with a common scalpel blade, electric scalpel, cryosurgery or carbon dioxide laser $[2,17]$. However, one study found that $38.5 \%$ of post- 
operative green turtles patients, has the tumors returned after 36 days [3] as well as the sea turtle in this study. The complications of surgical removal include difficulty in surgical closure of large areas of tissue, risk of secondary infection or anemia, anesthetic risk and a high rate of recurrence [9]. Even because of the slow metabolism of the species, the healing time of sea turtles can be extremely long, representing open surgical wounds, potential portals of entry for secondary infections, which can lead to the animal's death [8].

The electrochemotherapy has been used for the treatment of epithelial neoplasms in several animal species in an efficient and safe way to treat fibropapillomas in turtles, being free from adverse effects or without tumor recurrence, however the investment of this treatment is high [8]. In this case, homeopathic treatment was chosen in order to promote an efficient and less harmful treatment based on the Law of Similarity was adopted, aiming at the balance of the vital force of the patient, which the individual's own organism fights the aggressor agent [18].

Therefore, the protocol adopted was with Thuya occidentalis 30 $\mathrm{cH}$, due to its proven action in reducing inflammatory responses in animals, involving reduction of edema, inhibiting the migration of neutrophils at the site of inflammation, reducing vascular permeability and pro-inflammatory cytokines, oxidative stress, in addition to an immunomodulatory effect [10]. In order to increase the speed of remission of fibropapillomas, the patient received HPV Biotherapic $30 \mathrm{cH}$ as a association, maintaining the homeostasis of the organism, in an ideal process where the cure occurs through the reestablishment lasting health. In a study made with Magellanic penguins, pododermatitis was treatedquicklu and effectively with homeopathy [18]. Due to the slow metabolism of the reptiles, the treatment occurred for a longer period to observe the remission of the condition [3], exactly the opposite of birds that respond more quickly to homeopathy due to their faster metabolism $[18,19]$.

\section{Conclusion}

Ultra-diluted drugs have shown their effectiveness on the total reduction of fibropapiloma without causing recurrence, commonly observed in conventional treatment. So the animal's greater well-being is valued, without subjecting it to surgical and anesthetic procedures.

\section{Acknowlegments}

We thank all members of Sabina - Escola Parque do Conhecimento.

\section{Conflicts of Interest}

The authors declare that they have no conflicts of interest.

\section{References}

1. Rossi S, Sanchez-Sarmiento Am, Vanstreels Ret, Dos Santos Rg, Prioste Fes, et al (2016) Challenges in evaluating the severity of fibropapillomatosis: a proposal for objective index and score system for green sea turtles (Chelonia mydas) in Brazil. PLoS ONE 11: 1-11. [crossref]
2. Matushima ER, Longatto Filho A, Di Loretto C, Kanamura CT, Sinhorini IL, et al. (2001) Cutaneous papillomas of green turtles: a morphological, ultra-structural and immunohistochemical study in Brazilian specimens. Braz J Vet Res Anim Sci 38: 5154.

3. Page-Karjian A, Serrano ME, Cartzendafner J, Morgan A, Ritchie BW, et al. (2020) Molecular assessment of chelonid alphaherpesvirus 5 infection in tumor-free green (Chelonia mydas) and loggerhead (Caretta caretta) sea turtles in North Carolina, USA, 2015-2019. Animals 10: 1964. [crossref]

4. Marschang RE (2011) Viruses Infecting Reptiles. Viruses 3: 2087-2126. [crossref]

5. Jones K, Ariel E, Burgess G, Read M (2016) A review of fibropapillomatosis in Green turtles (Chelonia mydas). Vet J 212: 48-57. [crossref]

6. Flint M, Limpus CJ, Patterson-kane JC, Murray, PJ, et al. (2010) Corneal fibropapillomatosis in green sea turtles (Chelonia mydas) in Australia. J Comp Path 142: 341-346. [crossref]

7. Silva Junior ED (2016) Incidência de fibropapilomatose em tartarugas marinhas na bacia Potiguar RN/CE, Pós Graduação em Biologia Estrutural e Funcional para titulo de mestre Universidade Federal do Rio Grande do Norte - UFRN. 2016.

8. Brunner CHM, Dutra G, Silva CB, Silveira LMG, Martins MFM (2014) Electrochemotherapy for the treatment of fibropapillomas in Chelonia mydas. J Zoo Wildl Med 45: 213-218. [crossref]

9. Donnelly KA, Papich MG, Zirkelbach B, Norton T, Szivek A, et al. (2019) Plasma bleomycin concentrations during electrochemotherapeutic treatment of fibropapillomas in green turtles Chelonia mydas. J Aquat Anim Health 31: 186-192. [crossref]

10. Remya VK, Kuttan G (2014) Homeopathy remedies with antineoplastic properties have immunomodulatory effects in experimental animals. Homeopathy 1-9. [crossref]

11. Yetsko K, Farrell JA, Blackburn NB, Whitmore L, Stammnitz MR, et al. (2021) Molecular characterization of a marine turtle tumor epizootic, profiling external, internal and postsurgical regrowth tumors. Commun Biol 4: 1-16. [crossref]

12. Lawrance MF, Mansfield KL, Sutton E, SAVAGE AE (2018) Molecular evolution of fibropapilloma-associated herpesviruses infecting juvenile green and loggerhead sea turtles. Virology 521: 190-197.

13. Work TM, Dagenais J, Willimann A, Balazs G, Mansfield K (2020) Differences in antibody responses against Chelonid Alphaherpesvirus 5 (ChVH5) suggest differences in virus biology in ChHV5-Seropositive green turtles from Hawaii and ChHV5-Seropostive green turtles from Florida. J Virol 94: 1-15. [crossref]

14. Morrison CL, Iwanowicz L, Work TM, Fahsbender E, Breitbart M, et al. (2018) Genomic evolution, recombination, and inter-strain diversity of chelonid alphaherpesvirus 5 from Florida and Hawaii green sea turtles with fibropapillomatosis. Peer J 2: 1-33. [crossref]

15. Cárdenas DM, Cucalón RV, Medina-Magües LG, Jones K, Alemán RA, et al. (2019) Fibropapillomatosis in a Green Sea Turtle (Chelonia mydas) from the Southeastern Pacific. J Wildl Dis 55: 169-173. [crossref]

16. Vilca FZ, Rossi S, De Olinda RA, Sánchez-Sarmiento AM, Prioste FES, et al. (2018) Concentrations of polycyclic aromatic hydrocarbons in liver samples of juvenile green sea turtles from Brazil: Can these compounds play a role in the development of fibropapillomatosis? Mar Poll Bull 130: 215-222. [crossref]

17. Mader DR, Wyneken J, Weber ES, Merigo C (2006) Medical Care of Sea Turtles: Medicine and Surgery. In: Reptile Medicine and Surgery 76: 977-1000.

18. Narita FB, Scardoeli B, Gallo Neto H, Coelho CP (2020) Homeopathic treatment of pododermatitis in magellanic penguins (Spheniscus magellanicus). Homeopathy. [crossref]

19. Coelho C, Von Ancken ACB (2019) Uso da homeopatia na medicina clínica e preventiva de animais selvagens. Boletim técnico ABRAVAS Brasil.

\section{Citation:}

Narita FB, de Souza Balbueno MC, Scardoeli B, Neto HG, de Paula Coelho C (2021) Treatment of Fibropapillomatosis in a Green Sea Turtle (Chelonia mydas) Using UltraDiluted: Case Report. Integr J Vet Biosci Volume 5(2): 1-3. 